破断鋼材の破断面近傍補修溶接における鋼材の材料特性

および溶接継手性能について

\title{
ON MECHANICAL BEHAVIOR AND PROPERTY OF WELD JOINT FOR REPAIR AT THE NEARBY FRACTURE SECTION OF STEEL MEMBER
}

\author{
渡辺誠一*, 村上 心**, 木村 衛***, 金子洋 文***, 櫛 部 淳 道**** \\ Seiichi WATANABE, Shin MURAKAMI, Mamoru KIMURA, \\ Hirofumi KANEKO and Atsumichi KUSHIBE
}

\begin{abstract}
In order to evaluate the safety of the buildings the structures of which was repaired, it is very important to estimate the performance of the weld structural parts. This study is based on the experiment; after giving weld repair to the distorted SM490A steel member with weld joint in the condition which is like the actual weld work, we examined the mechanical behavior and property.

The study led to the following results.

1)In the cold condition, the toughness doesn't change after giving weld repair to the broken steel member with weld joint.

2) The weld repaired steel member has the lower tensile strength than the original member.

3)The steel member with more load than elasticity has the higher tensile and yield strength and the less deformation.

4) The weld repaired section has father improved on mechanical behavior in the cold condition than the pre-loaded member.
\end{abstract}

Keywords : steel member, weld joint, repair, mechanical behavior 鋼材, 溶接, 補修, 材料特性

\section{1.はじめに}

1995年1月17日に起きた兵庫県南部地震（M7.2、最度UI）におい ては、非常に大きな地酸動の入力により、鉄骨造建物の柱とはりの溶 接仕口部における破断や溶接部以外の母材での破断なぞ、多くの被害 が発生した。これら破断した仕口部の得に関しては通常損侽程度に よるが、塑性変形を大きく受けた破断面近培をガウジングし、補修溶 接するという方法が多く用いられている。

補修楁接部近傍においては、塑性ひずみ履歴を受けた部位への度重 なる入熱による、熟ひずみの発生や、組織変化、硬化等による、機械 的性買の劣化が照念される反面、溶接入熱を低く制御し、ビードを多 パスとるする等、補修溶接策件を道切に選ぶことで、カウジングや禣 修溶接時の再入熱による望性ひずみの解放および、焼鈍刹果による勒 性回復等の効果も同時に期待される。

例えば梁部材の場合には沟眍モーメントにより材軸方向に忘力勾 配が生じており、SM490やSS400等の応力ーひずみ関係では、ひず み硬化開始後 $5 \%$ 前後のひずみで引張強さの90\%を超える程度まで 応力度が上昇し、その後15２0\%の引張強さに対応するひずみまで 徐々に応力度が上昇すると考元られる。つまり、わすかな応力勾涫 によって引張強さに達した破断部の㭪修容接部の外側のひずみは $5 \%$ 〜10\%程度の予ひずみ量であると考えられる。また、スカラッブが
存在する場合にはその部分のひずみが增大し破断ひずみに達しても、 スカラップによるウェブ断面欠損のない領域まで塑性化が広がって も、その部分の発生ひずみは数％程度と思われる。このような観点か ら、塑性ひずをを受け機械的性質が少化した部位に関しては、溶接入 熱を低く制御し、ビードを多パスとする等の補修溶接条件を道切に選 ぶことで、相反する効果として、ガウジングや補修溶接時の再入熱に よる塑性ひずみの解放および、焼鈍硬化による勒性回復等の効果が期 待できれば、補修溶接部の耐力や勒性が改善され、梁部材の破断に対 する㚆形能力がかなり回復されると考える。

したがって、補修溶接部の再入熱による機械的性質の分化と勒性 回復の兼ね合いを十分に考慮することが重要である。しかしなが ら、このような観点からの補修溶接部の性能評価の検証の報告はほ とんどされていないと思われる。

よって、構造物のその後の安全性を評価するうえで、補修後の溶 接部を含む部材がどの程度の保有性能を維持するのかを総合的に評 価することが非常に重要となる。

このような背景から本研究では溶接継手を含むSM490A材に破断 ひずみに近い予ひずみを与えた後に、割れが梁端フランジ完全溶け 込み溶接部内、その溶接部から母材部、あるいはスカラップ底から 母材部へ進展するそれぞれの埸合の梁端フランジ完全溶け込み溶接
* 椙少女学園大学生活科学部生活環境学科 教授・博-1: ( ( 工学:

** 瑁山女学園大学生活科学部生活環境学科 講師・留

**** (侏竹中工務店技術研究所工博

**** 陎竹中工務占技術研究所工修
Prof., Dept. of Human Environment, Sugiyama Jogakuen Univ., Dr. Eng.

Lecturer, Dept. of Human Environment, Sugiyama Jogakuen Univ., M. Eng. Research and Development Institute, Takenaka Co., Dr. Eng. Research and Development Institute, Takenaka Co., M. Eng. 
部とガウシング後の補修溶接部との位置関係に着目して、その位置関 係が実際の補修工事に近い状態で補修溶接を行い、種々の塑性ひずみ 履歴および熱履歴等の諸因子の影響を受けた母材および溶接継手部の 機械的性質を評価した。

\section{2.研究の方法}

\section{1 試験フロー}

本試験では、図ー1に示すフローに従って、無載荷材と载荷材（予 ひずみ材）及び溶接材の各種性質を調查し比較検討を行う。試験項目 は以下の通りである。

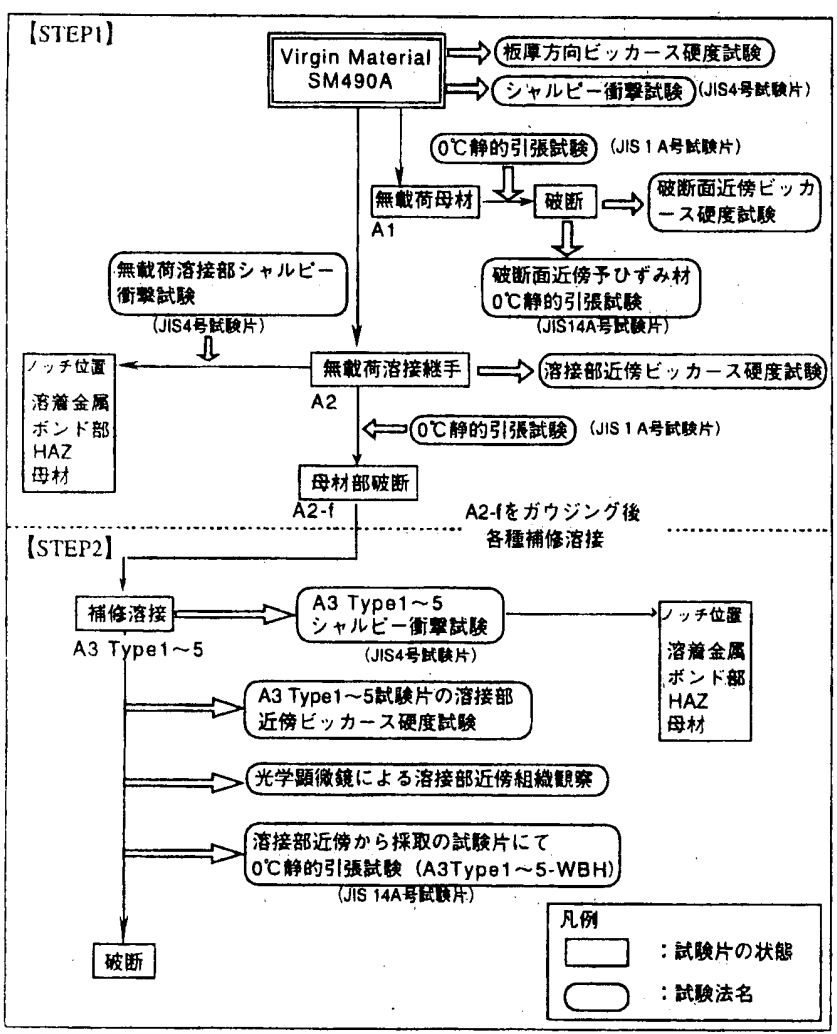

図ー 1 試験フロー

\section{1)静的引張試験}

摄氏 0 度での静的載荷を各々 2 回計測し、応力ーひずみの関係及び 伸び性能を調べる。使用する供試体は、A1,A2,A3Type 1 5-WBH の 4 種類および載荷母材 (JIS14A号) である。（供試体の設定条件に 関しては、2.2節を参照。)

2) ビッカッース硬度試験

常温で供試体平行部の厚さ方向中心 $1 / 2 \mathrm{t}$ の位置において長手方向の 試験を行い溶接部および破断面近傍の硬度分布を求める。供試体は、 無載荷材（Virgin材）,A1（破断面近傍）,A2,A3Type1 5破断面近 傍の母材の8種類である。

3)シャルピー衝撃試験

エネルギー吸収能力に及ぼす採取位置、塑性ひずみ履歴等による差 異を明らかにする。摄氏0度で各3回計測の平均值で評価する。試硔片 採取位置は、板厚中心から、溶着金属部、ポンド部、 $\mathrm{HAZ}$ ～部、母材 部とする。供試体は、Virgin材, A2, A3Type1〜5拉よび予ひずみ材 である。ここに、予ひずみ量は補修溶接する前の供試体を破断させて 引張強さに対応するひずみ量を与える。ただし、載荷前の溶接部は供
試体の母材の引張強さをを余盛分を含む面積で除した平均応力度に対 応する予ひずみ量となる。一方、補修溶接部の予ひずみ量は0であ る。

\section{4)組織観察}

A3Type1〜5については光学影微鏡によるミクロ組織観察を行い、 塑性ひずみ履歷及び熱履歴による素材の組織変化を調べた。

\section{2 供試体}

1)各種条件

鋼種は溶接構造用圧延鉡材SM490Aを用いる。板厚は $\mathrm{t}=16 \mathrm{~mm}$ と する。溶接は、表一2に示す条件での完全溶込溶接とし、裹当金、工 ンドタブを用いる。溶接線は、材軸方向に直行方向とする。なお、 $\mathrm{CO}_{2}$ 半自動溶接による溶接条件は、 $\Phi 1.2$ の溶接棒を用いて、板厚

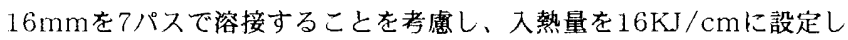
ている。これは筆者らが塑性ひずみ履歴を受けた鋼材の補修溶接に際 し、通常よりも低入熱量で多バスの補修溶接を行うことを意図したも のである。又、ここでは以下の理由により残留応力の影響は考慮して いない。建て方時に両端の柱の拘束度によっては梁材軸方向に残留応 力が生ずる可能性がある。しかし、梁下フランジが破断した場合には 建て方時に発生した残留応力や長期荷重による応力が部材断面内にお いて応力の再配分により下フランジにおいて一旦解放されると考兄ら れる。補修溶接時にはスラブの梁材軸方向に対する拘束もあり、残留 応力は再び発生すると予想される。部材断面内の底力の釣合状態に抒 いて補修溶接部に生じる残留応力の大きさは降伏応力レベル前後と なっていることも考えられるが、そのひずみレベルは $0.15 \%$ 前後であ る。しかしながら、ここで対象とする溶接時の性能に及ぼす影響を評 価するひずみレベルは引張強さに対応するもので、それは $15 \%$ 20\% 程度の大きな値である。

表 -1 使用鋼板のミルシート

\begin{tabular}{|c|c|c|c|c|c|c|c|c|}
\hline \multirow{2}{*}{ 鋼·種。 } & \multirow{2}{*}{$\mathrm{mm}$} & \multicolumn{5}{|c|}{ 化 学 成 分 } & \multirow{2}{*}{$\begin{array}{l}\text { 降伏応力 } \\
\mathrm{N} / \mathrm{mm}^{2}\end{array}$} & \multirow{2}{*}{$\begin{array}{l}\text { 抗張力 } \\
\mathrm{N} / \mathrm{mm}^{2}\end{array}$} \\
\hline & & C & $\mathrm{Si}$ & $\mathrm{Mn}$ & $\mathrm{P}$ & S & & \\
\hline SM490A & 16 & 0.17 & 0.42 & 1.41 & 0.015 & 0.004 & 383 & 545 \\
\hline
\end{tabular}

表 -2 溶接及び補修溶接の条件

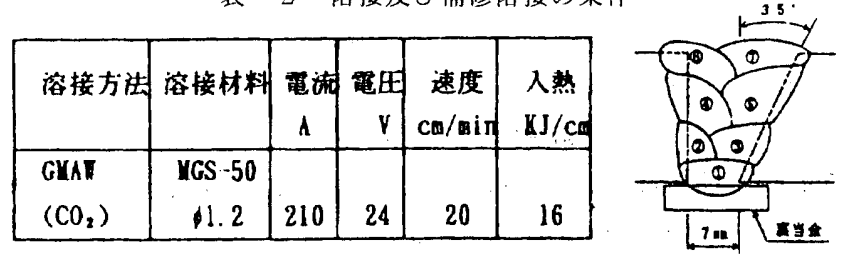

2)供試体A1（無載荷母材）

鋼板よりJIS1A号試験片を製作した。

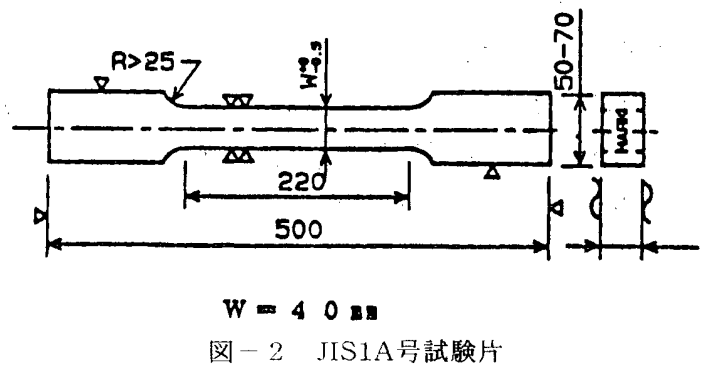




\section{3)供試体A2（無載荷溶接材）}

鋼材を完全溶込溶接したJIS1A号試験片とし、母材、HAZ、溶着金 属で構成される。なお、裏当金および余盛はそのままとする。

4) 供試体A2-f（載荷母材）

$\mathrm{A} 2$ 試験片を引張試験し破断させた供試体である。

写真一1にA2試験片の破断状況を示すか゚、一部重当金止端部から破 断したものがあったが、試験では母材で破断したもののみを用いてい る。

5)供式体A3（補修溶接材）

$\mathrm{A} 2-\mathrm{f}$ 試験片の破断面近傍をガウジングし、旧溶接部からの距離と熱 履歴をパラメータとして補修溶接を行った供試体である。これは割れ が、溶着金属から母材に入る場合の元の溶接部と破断面の位置関係を 想定したもので補修溶接位置と破断位置は必ずしも一致していない。

いずれのTypeも破断面近傍および補修溶接部近傍に 2 度の熱履歴 を受けている。溶接の方法をType1〜5の 5 種類とした。

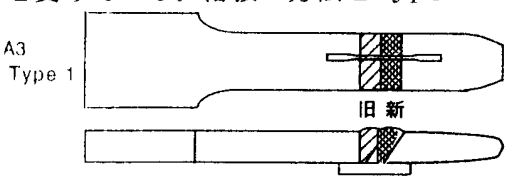

元の接合部をそのまま残し、㭪修溶接部 一部意図的にオーバーラップさせたもの
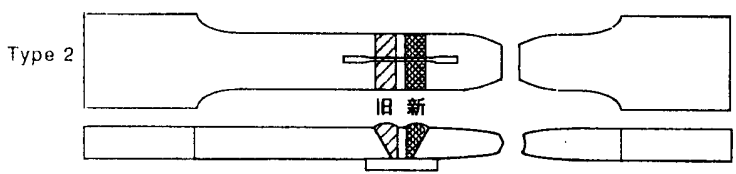

元の接合部をそのまま残し、㭪修溶接部を 施工上の限界まで近接させたもの

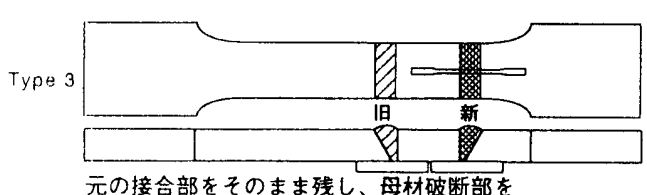

ガウジングし、㭪修溶接したもの
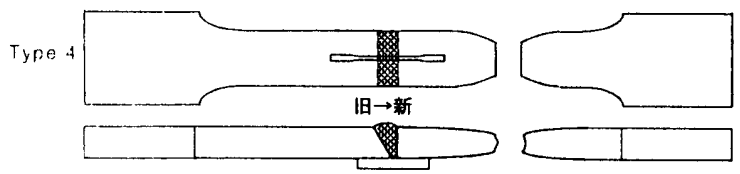

元の接合部をガウジングし、補修溶接したもの

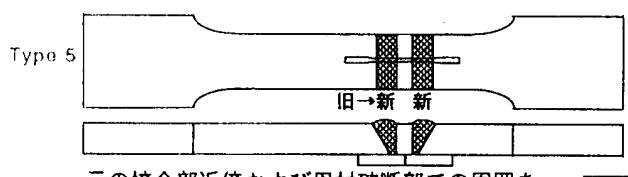

元の接合部近傍および母材破断部での周囲を 斯にガウジングし、㭪修溶接部を施工上の限

界まで近接させたもの

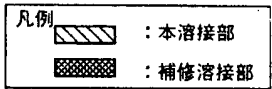

図 -3 載荷後の補修溶接位置およびJIS14試験片の採取位置

6)供試体A3WBH（載荷溶接材）

A3試験片の溶接部近傍から取り出した、A3Type1〜 5補修溶接部 及び熱影響部を平行部とするJIS14A号試馱片である。

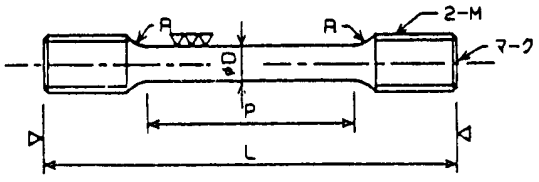

$\phi D$ P

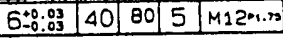

7)シャルピー衝撃試験の供試体

シャルピー衝撃試験の形状及びノッチの採取位置は図ー5，6 とす る。

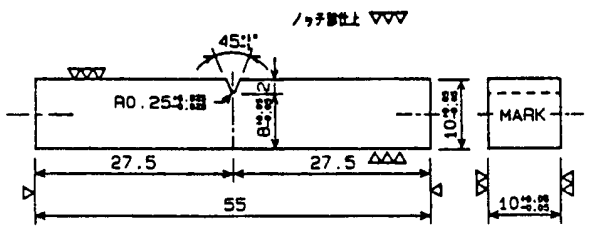

図- 5 シャルピー試験片の形状

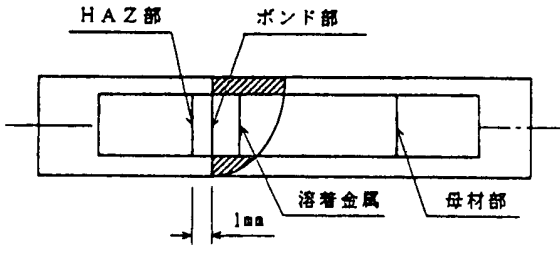

図ー6 シャルピー試験片の採取位置

\section{3.詰项結果及び考察}

\section{1 静的引張試験}

引張試験の結果を表- 3 および図-7、図-8に、引張試験後の破断 状況の例を写真 -1 に示す。また、結果を平均値でまとめたものを図 -9に示す。

まず、試験片形状の違いによる検討を行うとJIS14A号丸棒試験片 は、JIS1A号板状試験片に比してやや耐力が低く引張強さ（抗張 力）が高くなり、降伏比では約6\%低くなるが機械的性質を比較する 上で大きな差は生じていない。

無載荷の母材（A1）と継手材（A2）を板状試験片で比較すると、 耐力においてやや継手材の值が低いが、引張強さには殆ど差はみられ ない。しかし、降伏比は、継手材がやや低い。伸び及び絞りについて は、継手材が数\%前後低い値を示す。これは、溶接部の性状によるも のであると考えられる。

載荷により、引張強さに達した母材は、ひずみ硬化により、耐力、 引張強さいずれも約 $200 \sim 300 \mathrm{~N} / \mathrm{m}^{2}$ 上昇する。これは、耐力で約 $80 \%$ 、引張強さで約 $25 \%$ の上昇にあたる。ただし、引張強さの上昇 は真応力で比較すると $10 \%$ 程度である。この上昇は、ひずみ硬化の他 に予ひずみを与えた時期と載荷時期の差である約 3 力月のひずみ時効 の影響も受けていると考えられる。降伏比は、約65\%から約 $95 \%$ へ約 $30 \%$ 上昇する。伸びは、約35\%から約 $15 \%$ へ約 $20 \%$ 減少する。就り も約 $75 \%$ か約 $65 \%$ とやや減少傾向である。

載荷継手の引張試験片JIS14A号の破断部位は全て溶接ボンド部であ り、載荷母材之載荷継手を比較すると、継手の耐力、降伏比（約 $95 \%$

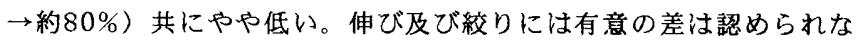
い。特にType3は、高い降伏比を示しているが、溶接による熱影響が 少ないためであると思われる。なお、このような性質の部位が部材軸 方向に広がっている場合には、破断後補修した部材の伸び変形や回転 能力が無載荷の部材に対してかなり劣化することになる。

図-4 JIS14A号試験片 

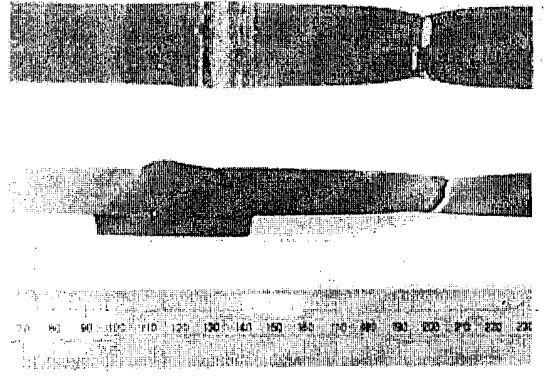

写真 -1 静的引張試験後の破断状況

表一 3 静的引張試験の試験結果

\begin{tabular}{|c|c|c|c|c|c|c|c|}
\hline 理取来件 & 武版版状 & $\begin{array}{l}\text { 艚力 } \\
\mathrm{N} / \mathrm{nd}\end{array}$ & 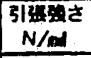 & $\begin{array}{c}0+1 \\
\%\end{array}$ & $\begin{array}{c}\text { 饰ひ } \\
\% \\
\end{array}$ & $\begin{array}{c}0.4 \\
\% \\
\end{array}$ & 觜考 \\
\hline \multirow{2}{*}{ 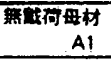 } & \multirow{2}{*}{ 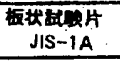 } & 398 & 519 & 72.5 & 26.0 & 30.0 & \\
\hline & & 401 & 551 & 72.8 & 26.2 & 31.0 & \\
\hline \multirow{11}{*}{ 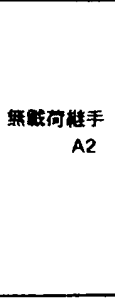 } & \multirow{11}{*}{$\begin{array}{c}\text { 板状新期片 } \\
\text { JIS-1A }\end{array}$} & 386 & 558 & 69.2 & 21.2 & 25.9 & \\
\hline & & 390 & 557. & 70.0 & $22: 3$ & 26.2 & \\
\hline & & 386 & 556 & 89.1 & 20.1 & 27.5 & \\
\hline & & 387 & 556 & 69.6 & 21.2 & 26.7 & \\
\hline & & 382 & 557 & $68: 6^{\circ}$ & 22.0 & 27.5 & \\
\hline & & 384 & 556 & 69.1 & 20.5 & 26.2 & \\
\hline & & 388 & 558 & 69.5 & 20.3 & 28.5 & \\
\hline & & 388 & 557 & 69.8 & 21.0 & 27.3 & \\
\hline & & 883 & 556 & 68.9 & 20.9 & 26.4 & \\
\hline & & 385 & 556 & 69.2 & 22.9 & 27.5 & \\
\hline & & $3 B 5$ & 558 & 69.0 & 21.0 & 27.0 & \\
\hline \multirow{4}{*}{ 製盛回母材 } & \multirow{4}{*}{$\begin{array}{c}\text { 丸模斌墤片 } \\
\text { JIS-14A }\end{array}$} & 377 & 573 & 65.8 & 34.0 & 75.1 & \\
\hline & & 388 & 568 & 68.3 & 36.0 & 75.1 & \\
\hline & & 366 & 567 & 64.6 & 33.3 & 73.1 & \\
\hline & & 379 & 572 & 66.3 & 33.3 & 75.1 & \\
\hline \multirow[t]{2}{*}{ 期司母材 } & \multirow{2}{*}{ 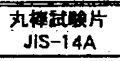 } & 685 & 724 & 94.6 & 16.3 & 69.7 & \\
\hline & & 675 & 715 & 94.1 & 12.7 & 66.1 & \\
\hline \multirow{11}{*}{$\begin{array}{l}\text { A3 } \\
\text { A3 } \\
\text { Typel } \sim 5 \\
\text { WBH }\end{array}$} & \multirow{11}{*}{ 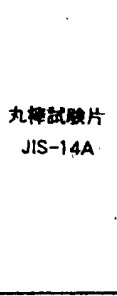 } & 521 & 612 & 01.2 & 17.7 & 71.6 & Typel \\
\hline & & 517 & 647 & 79.8 & 18.0 & 71.7 & \\
\hline & & 520 & 658 & 80.2 & 17.3 & 69.9 & \multirow[t]{3}{*}{ TYDe2 } \\
\hline & & 199 & 638 & 78.2 & 19.3 & 65.7 & \\
\hline & & 523 & 641 & 81.6 & 18.0 & 91.6 & \\
\hline & & 513 & 645 & 84.2 & 19.0 & 62.1 & \multirow[t]{2}{*}{ Types } \\
\hline & & 598 & 653 & 91.6 & 15.0 & 60.0 & \\
\hline & & 481 & 635 & 13.7 & 16.7 & 60.0 & \multirow[t]{2}{*}{$T y, g=4$} \\
\hline & & 508 & 637 & 79.7 & 15.0 & 60.0 & \\
\hline & & 194 & 640 & 77.2 & 18.3 & 62.1 & \multirow[t]{2}{*}{ Types } \\
\hline & & 187 & 637 & 76.5 & 19.7 & 66.1 & \\
\hline
\end{tabular}

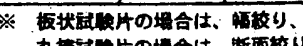
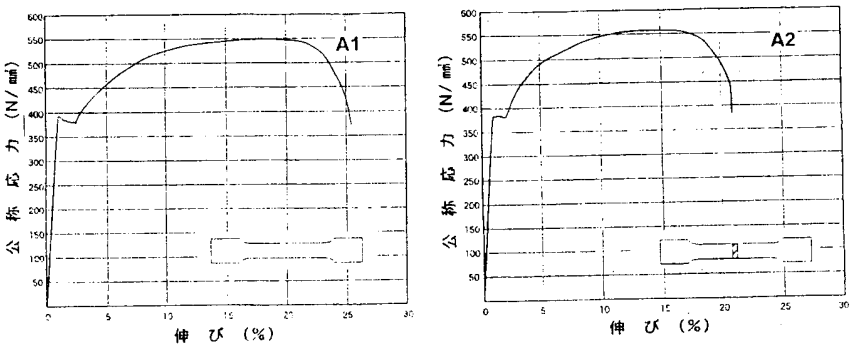

図一7 試験体 $\mathrm{A} 1$ 及びA2の代表的な応力ーひずみ曲線

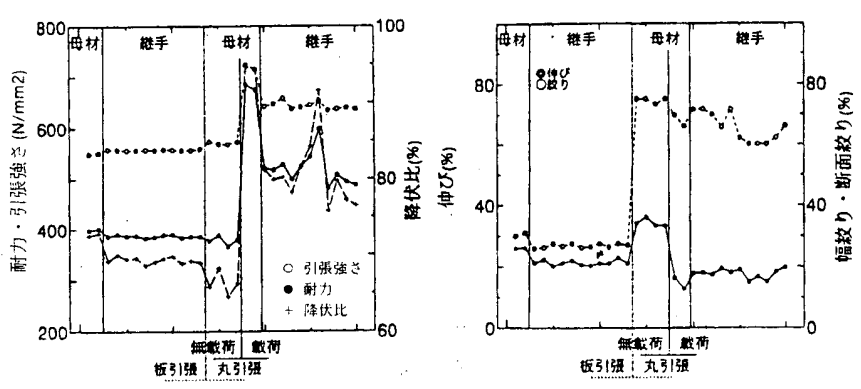

図-8 採取条件と耐力・引張強さ及び伸びの関係

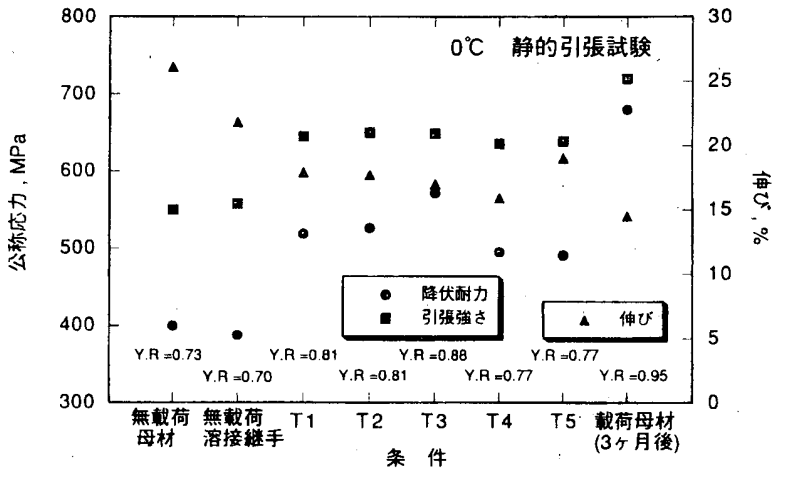

図-9 各種試験片の耐力・引張強さ・伸びの比較

\section{2 ビッカース強度試験}

図一 10 に無載荷母材の板厚方向のビッカース硬度を示すが、板厚方 向に㩆著な差は見受けられず、約 $150 \mathrm{Hv}$ 程度の硬さ分布である。次に 図ー11にこの母材を引張破断させた後の破断面近傍の板厚中央での硬 度と板厚変化を示す。これより、引張強さを示す程度まで塑性ひずみ を受けた母材部の硬度は約 $200 \mathrm{Hv}$ 程度まで上昇し、破断面近傍のしほ り変形の激しい部分においては約 $240 \mathrm{Hv}$ 程度にまで達していることが わかる。
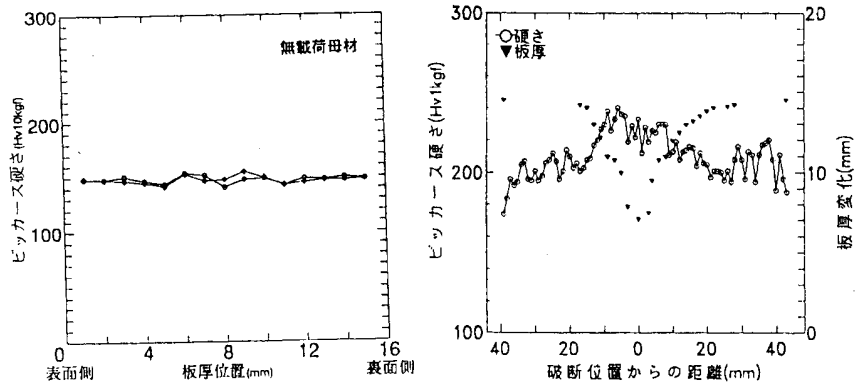

図-10 母材板厚方向硬さ分布 図-11 引張試験後に㧍ける板厚中 央位置の硬さと板厚変化

次に図-12に無載荷溶接継手、そして、図-13〜図-17に補修溶 接行った状態であるType1〜5（図-3参照以下T1〜T5）の硬度分布 を示す。なお、図中の溶接部の模式図は、最初に存在したものを、 旧、引張試験後補修溶接の際に行ったものを新として区別している。 計測は試験片の板厚方向に上面から $1 \mathrm{~mm}$ (上面）、板厚中央（中 央）、下面から $1 \mathrm{~mm}$ (下面) の3箇所で行った。図一-12より母材の溶 接継手近傍でのビッカース硬度は、溶接により全体的に增加し、熱影 響部において約 $200 \mathrm{Hv}$ 程度まで上昇することがわかる。また、溶接の 最終パスのポンド部では、局部的に硬化した部分が見られる。

次に、引張破断後、補修溶接を行った図ー13〜図-17の硬度試験結 果より、いずれのタイプの補修溶接方法を用いても、板厚中央の硬度 分布は $200 \mathrm{Hv}$ 前後の値を示した。

すなわち、一様に大きな予ひずみを受けた母材に補修溶接を行っ ても、入熱の影響及び予ひずみによる顕著な硬度上昇をほとんど起 こさないことが明らかとなった。 

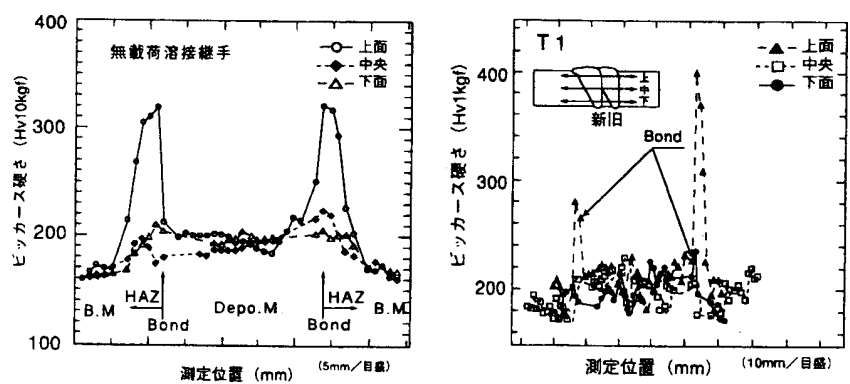

図-12 無載荷溶接部の硬さ分布 図-13 $\mathrm{T} 1$ 溶接部の硬さ分布
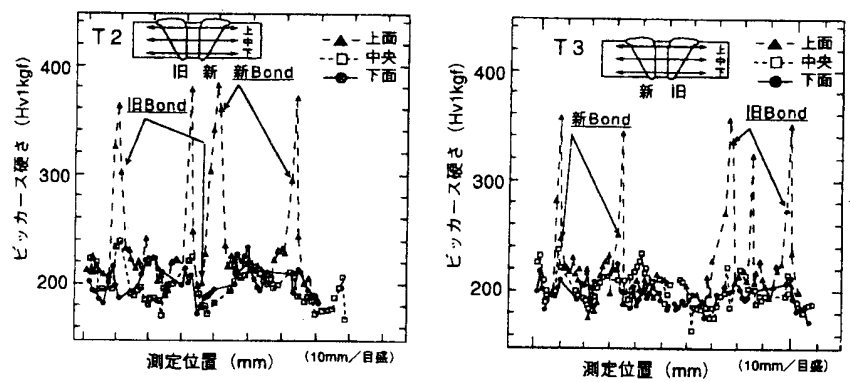

図-14 T2溶接部の硬さ分布

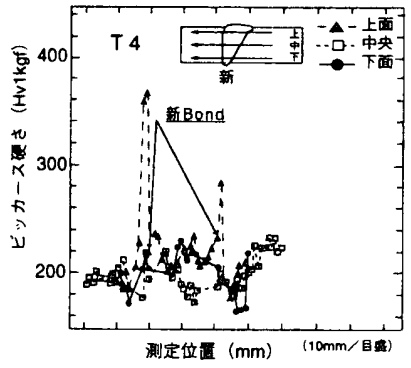

図-16 T4溶接部の硬さ分布

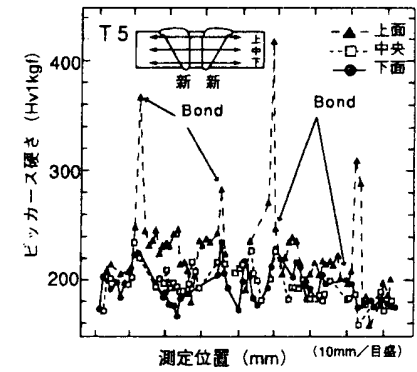

図 -17 T5溶接部の硬さ分布

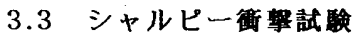

引張試験前後での母材および溶接継手部近傍の低温勒性を調查する ため、シャルピー衝撃試験を行った。ノッチは板厚中央部から採取 し、試験温度は $0^{\circ} \mathrm{C} に て$ 行った。結果は、3回計測の平均値で評価し、 検討を加えている。

表ー4に無載荷の溶接部及びT1〜T5の補修溶接部の各位置での試験 結果を示す。また、図ー18に各種武験片のシャルピー衝撃値の比較を 図示したものである。これらより無載荷の溶接部の溶着金属および HAZは150〜160J/m衝撃値を示すのに対し、ボンドおよび母材は $100 \mathrm{~J} / \mathrm{m}$ mª程度であった。

また、破断後補修溶接を行った $\mathrm{T} 1$ T 5 試験体の母材及び各部位の シャルピー衝撃試験結果から、補修溶接部近傍に関しては、どのタイ プの補修溶接方法を用いても、衝撃值が無載荷の溶接部と比べて大き く劣化したものはなかった。それに対し、補修溶接部から離れた母材 部では、衙撃值が無載荷母材より著しく劣化する結果となった。これ は、母材部では予ひずみが解放されず材質劣化を起こすのに対し、補 修溶接部近傍では、破断した部位をガウジング後、補修溶接を行うと いった熱サイクルの付加によって焼鈍効果を生じ、補修溶接部近傍の

母材に与えられていた予ひずみが解放されたことによるものと思われ る。これは、T1〜T5の条件の中で旧溶接部が補修溶接部から最も離 れて位置し、補修溶接入熱による影䇺を受けにくいT3旧溶接部の HAZの䩗性值が他のタイプに比べ低いことからも裏付けられる。

表 -4 溶接部近傍でのシャルピー衝撃試験結果

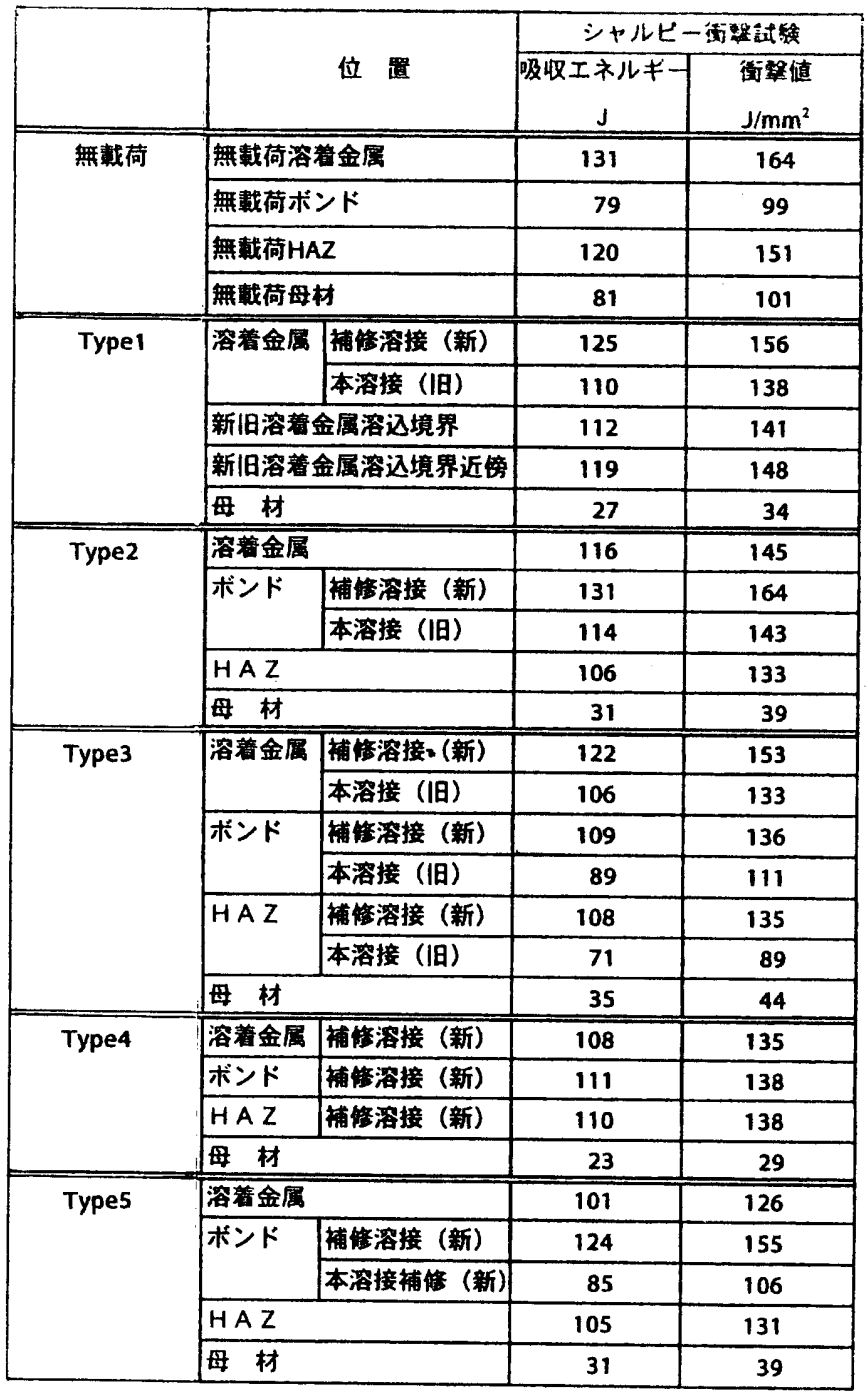

* 趾黩温度 : $0^{\circ} \mathrm{C}$

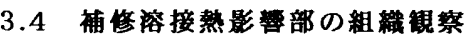

ビッカース硬度試験およびシャルピー衝撃試験により得られた結果 と、補修溶接部の熱影響部のミクロ組織との対応を調查するため、光 学顫微鏡による組織観察を行った。写真 $-2 \sim 4$ に例として、T1の補修 楁接部溶着金属、ボンド部、熱影響部の板厚中心付近におけるミクロ 組織写真を示す。なかでも複雑な溶接熱サイクルを受ける熱影響部に おいても全般的には微練なフェライト及びベイナイトからなる組織で あり、カウジング及びその後の溶接による溶接熱サイクルの付加によ り熱影警部に赖念されるような、結晶粒粗大化等の材質的な劣化はみ られず、むしろこの熱サイクルによる暁鈍勃果及び焼き戻し効果が生 じ、引張性質や低温勒性が、予ひずみを受けた母材部より改善された と考元られる。 

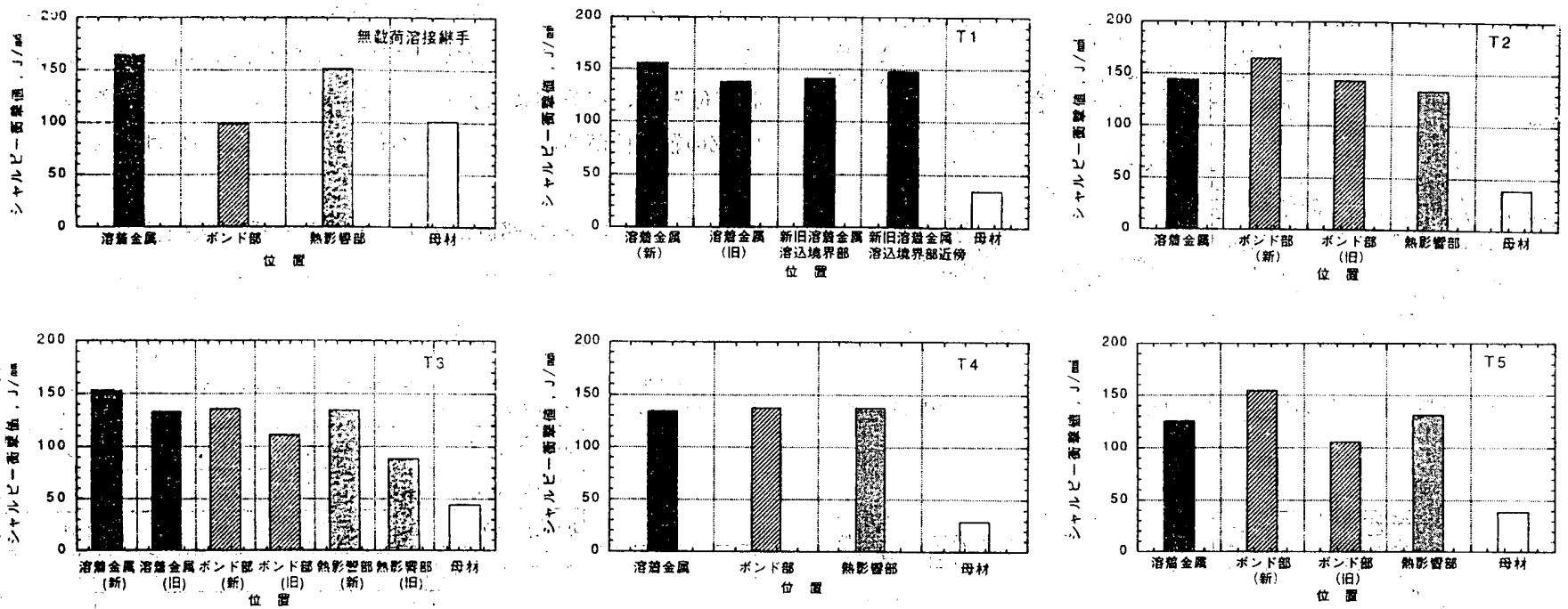

図-18: 各種試験片のシャルピー衝撃値の比較

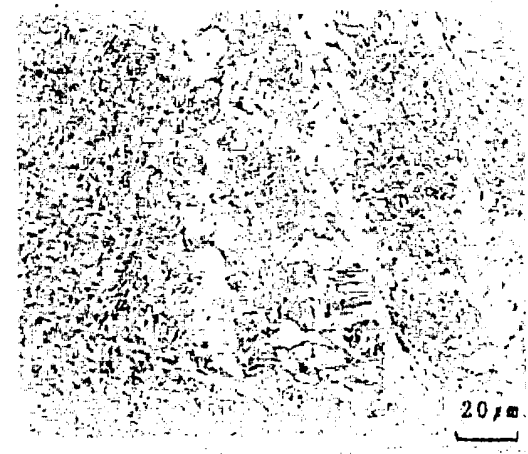

写真 -2 T1 補修溶接溶着金属部のミクロ組織

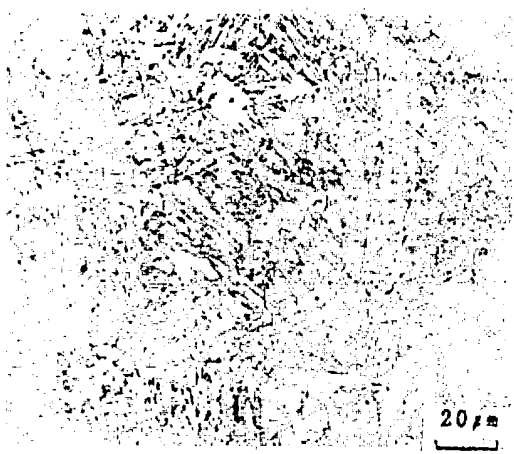

写真 -3 T1補修溶接ボンド部のミクロ組織

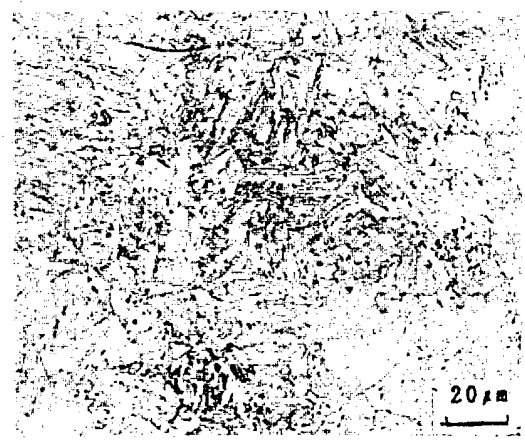

写真 -4 T1補修溶接熱影響部のミクロ組織

\section{4.おわりた}

地震等により構造物の溶接仕口、継手が破断した場合の溶接補修に 関して、その部分の機械的性質の評価を行うため、モデルとして無載 荷鋼材に溶接継手を設け、それらを静的引张により破断させ、種々の 補修溶接を行った。それらについて、引張試験、ミクロ組織観察、

シャルピー衝撃試験、ビッカース硬度試験、等により、以下のような 結果を得た。

1）無載荷の溶接継手部と破断して補修溶接した後の溶接継手部の低 温勒性を比較すると、母材の勒性は30\%程度まで低下しているが、 溶着金属、ボンド部、そして熱影響部の䩓性に顕著な変化は認めら れない。

2）母材と、健全な溶接継手の引張試験の結果を比較すると、母材よ りも溶接手の耐力や降伏比が若干低くなっている。

3）引張試験後の破断面近傍の母材は、加工硬化（ひず硬化）およ びひずみ時効の影響もあり、降伏比が約 $95 \%$ にまで達した。その部位 をガウジングして補修溶接した後に溶接部近傍の引張試験を行っても 脆性破断せずに引張強さに達した。また、付加される熱サイクルによ り、溶接ボンド部で破断したが、降伏比は 80 \%程度まで改善され、無 載荷母材に溶接継手を設ける場合に、無載荷母材の降伏比は7 $70 \%$ \%゙あ るが、それに近づいており、補修溶接部は継手としての保有性能がほ ほ満足される。

4）補修溶接継手部の熱影響部のミクロ組織は、ベイナイトおよび微 練なフエライトからなる組織となり、補修溶接の前後で硬度および 低温勒性に大きな変化注生じず、結果的に予ひずみを受けたままの母 材に比べ機械的性質が大きく改善される。ただし、溶接継手部の硬さ 分布に極度に高い硬さを示す部分がある。

以上のことから補修溶接継手およびその近傍の母材については再入 熱による予ひず夕の解放の効果が大きく、同時に起こる加熱・拘束に よる組織変化、硬化の影響が少なく、本実験結果からみるかぎり、補 修溶接部の保有性能はほとんぞ問題がないといえる。ただし、応力勾 配がほとんどない場合には、補修溶接部や母材は引張強さまで部材耐 力が保証されるので、その部位については強度的な設計が考えられ る。 
本研究は椙山女学園大学と竹中工務店技術研究所との共同研究であ る。本研究費助成として、椙山女学園大学研究費助成 (C) によって いることを付記し、感謝の意を表します。

\section{㐱考文献}

1）洨辺誠一：阪神震災における鉄骨梁フランジ破濖例とその破断面近傍の材料 の機械的性質について, 椙山女学園大学研究論集第27号「自然科学編」, pp. $149 \sim 161,1996.3$

2）波辺誠一，村上心，木村衛，金子洋文，櫛部渖道：破断鋼材の破断面近傍補修 溶接における鋼材の材料特性及び溶接䛧手性能について その1 研究方法と

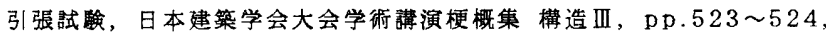
1997.9

3）筑部淳道，木村衛，金子洋文，淁记誠一，村上心：破断鋼材の破断面近傍補修 溶接における鋼材の材料特性及び溶接継手性能について その2 硬さ試験、 䩲性試駼他, 日本建築学会大会学術講演梗概集, pp.525 526, 1997.9

4) 材料強度学, pp. $21 \sim 24$, 社团法人日本材料学会

5) 材料強度工学ハンドブック, pp. $46 \sim 84$, 朝倉書店

(1997年10月 3 日原稿受理, 1998年 5 月 8 日採用決定 